\title{
Problematika Kurikulum dan Pembelajaran Pendidikan Karakter
}

\author{
Siti Julaeha \\ Sekolah Tinggi Agama Islam (STAI) Miftahul Huda Al-Azhar, Banjar \\ Email: julaikha425@gmail.com
}

Received: February 18, 2019 | Accepted: June 22, 2019

\begin{abstract}
Curriculum plays an important role in realizing future generations that are useful for the nation and state. Who has the nature of responsibility, creative, innovative, and become an expert. The curriculum is the heart of a school and the school is the heart of society and the society is the heart of the nation. So that the nation will advance if it has high quality and high quality of human resources. This study aims to identify curriculum and learning problems of character education. The research uses literature review method. The study results a number of character education curriculum and learning problems, that are the formulation of character education curriculum is still below the group's political interests. The character education curriculum also overlaps with the civic education curriculum, Pancasila education, and religious education. Meanwhile, the problem of character education learning boils down to methods, an educational environment that is not conducive, and the loss of example from parents. However, curriculum development often finds many problems that require consideration and solution from the discussion of definitions, scope, characteristics, principles, objectives, concepts, as well as curriculum development and as well as learning and character education which are emphasized in the national curriculum.
\end{abstract}

\begin{abstract}
Abstrak
Kurikulum berperan penting dalam mewujudkan generasi masa depan yang berguna bagi bangsa dan negara yang memiliki sifat tanggung jawab, kreatif, inovatif, dan menjadi seseorang yang ahli. Kurikulum adalah jantungnya sebuah sekolah dan sekolah itu adalah jantungnya masyarakat juga masyarakat itu adalah sebagai jantungnya negara atau bangsa, sehingga bangsa akan maju apabila memiliki sumber daya manusia yang berkualitas dan bermutu tinggi. Namun demikian perkembangan kurikulum sering menemukan banyak masalah yang memerlukan pertimbangan dan solusinya. Kajian ini bertujuan untuk mengidentifikasi problem-problem kurikulum dan pembelajaran pendidikan karakter. Penelitian menggunakan metode kajian pustaka. Dari hasil kajian diperoleh temuan sejumlah problem kurikulum dan pembelajaran pendidikan karakter, yaitu perumusan kurikulum pendidikan karakter masih di bawah kepentingan politik kelompok. Kurikulum pendidikan karakter juga tumpang tindih dengan kurikulum pendidikan kewarganegaraan, pendidikan Pancasila, dan pendidikan agama.
\end{abstract}


Sementara itu, problem pembelajaran pendidikan karakter bermuara pada metode, lingkungan pendidikan yang tidak kondusif, dan hilangnya keteladanan dari orang tua.

\section{Keywords}

Curriculum problems, learning problems, character education

\section{Pendahuluan}

Kebahagian, kesuksesan, dan kegagalnya seseorang, bahkan berhasil tidaknya sebuah rumah tangga dan maju mundurnya suatu bangsa. Semuanya dipengaruhi oleh sesuatu yang dinamakan karakter, karena karakter merupakan hal yang paling utama dan mendasar. Karakter sebagai mahkota hidup seseorang karena dengan karakter tersebut bisa membedakan antara manusia dan hewan.

Manusia yang tidak berkarakter disebut manusia yang melampaui batas karena syarat untuk bisa disebut manusia antara lain memiliki kemampuan dalam mengendalikan diri, cinta tanah air, berpengetahuan. Bung Karno sebagai bapak presiden pertama negara republik Indonesia menegaskan "Bangsa ini harus dibangun dengan mendahulukan pembangunan karakter (character building) karena pembangunan karakter akan menjadikan Indonesia menjadi negara yang besar, jaya dan maju. Bila pembangunan karakter ditinggalkan maka bangsa Indonesia akan menjadi bangsa kuli” (M. Samani \& Hariyanto, 2011, p. 2). Jadi bangsa yang berkarakter baik dan kuatlah yang mampu menjadikan bangsa itu disegani oleh bangsa lain.

Akhir-akhir ini bangsa mengalami berbagai peristiwa yang membuat cemas para generasi muda dan masyarakat luas tentang munculnya berbagai masalah. Di antaranya masalah korupsi yang tidak pernah habisnya menjadi topik pembicaraan di berbagai media masa, maraknya berita hoax (palsu) yang membuat kericuhan dan kegelisahan rakyat banyak. Cyber bullying yang melanda generasi muda, orang dewasa sampai kalangan yang lebih tua seperti yang sudah tidak ada aturan atau adab sopan santun dalam berbicara baik di dunia nyata maupun di dunia maya, saling mencaci maki, saling menjatuhkan dengan membuka aib lawan bicaranya. Contoh lain yang terjadi pada permasalahan karakter yaitu tentang prostitusi yang membuat khawatir dan gelisah masyarakat luas, ini menunjukkan kemerosotan moralitas atau karakter bangsa saat ini.

Kemerosotan moralitas atau karakter menurut data hasil survey mengenai seks bebas dikalangan remaja mencapai 65\%. Menurut Direktur BKKBN, M 
Masri Muadz, mengatakan bahwa permasalahan narkoba mencapai 1,1 juta orang. Berdasarkan indeks persepsi korupsi (IPK) Indonesia berada diurutan 3 dari 180 kemiskinan yang mencapai 40 juta dan terus bertambah (Koesoema, 2010, p. 3).

Fenomena yang terjadi pada bangsa Indonesia ini merupakan bukti nyata adanya kemerosotan karakter. Jika diingat kembali bangsa Indonesia bersamasama menyepakati untuk memproklamasikan kemerdekaan tanggal 17 Agustus 1945 bahwa pembentukan Negara Indonesia berdasarkan pada etika-etika luhur bangsa Indonesia yaitu mendirikan negara yang bersatu dan membangun karakter (M. Samani \& Hariyanto, 2011, p. 1).

Pada Hari Pendidikan Nasional tanggal 2 Mei 2010 presiden Republik Indonesia mencanangkan pelaksanaan gerakan pembangunan karakter bangsa. Begitu juga pada tanggal 2 Mei 2011, Muhammad Nuh sebagai menteri pendidikan mencanangkan tema peringatan hari pendidikan dengan tema pendidikan karakter sebagai pilar kebangkitan bangsa, untuk meraih prestasi dan budi pekerti yang luhur.

Karakter dapat dibentuk melalui pendidikan karakter, yang merupakan pendidikan akhlak, adab dan sesuatu yang paling utama di prioritaskan dalam ajaran Islam. Pendidikan karakter secara teoritik telah ada sejak Islam turun ke dunia dan sebagai suatu alasan Nabi Muhammad diutus ke muka bumi. Islam mengajarkan tidak hanya pada aspek keimanan saja atau aspek ibadah saja (muamalah) tetapi pada aspek akhlak (karakter) juga Islam sangat menganjurkan bahkan Rasulullah sebagai tutorial Pendidikan karakter yang pertama model karakter Nabi Muhammad yang memiliki sifat shidiq, fatonah, tablig, amanah itu sungguh luar biasa (Mulyasa, 2012, p. 5).

Dalam Alquran yang menjelaskan tentang akhlak atau karakter terdapat 1.540 ayat.Ini menunjukan Islam dari awal memperhatikan sekali terhadap akhlak atau karakter. Karena akhlak merupakan fondasi utama manusia sepanjang sejarah. Suatu ungkapan "Characters isn't inherited. One builds its daily by the way one thinks and acts, thought by thought, action by action" (Jerome, Kisby, Jerome, \& Kisby, 2019a, p. 14).

Karakter tidak diwariskan, tetapi sesuatu yang dibangun secara berkesinambungan hari demi hari melalui pikiran dan perbuatan, pikiran, tindakan demi tindakan ((M. Samani \& Hariyanto, 2011, p. 41). Maka dari itu pendidikan karakter atau akhlak sebaiknya diusahakan atau dibentuk dari usia dini sehingga karakter tertanam kuat pada diri seseorang karena seseorang ketika mengambil keputusan tidak akan terlepas dari pendidikan yang diperolehnya

Intinya dari pendidikan karakter membentuk bangsa yang tangguh, berakhlak mulia, kompetitif, bertoleran, bermoral, berjiwa patriotik, 
berkembang dinamis, gotong royong. Sehingga kesemuanya itu diolah dalam pembelajaran yang merupakan bagian dari kurikulum. Kurikulum sebagai pusat publikasi bahwa pendidikan karakter berfungsi sebagai pengembang potensi dasar agar berhati baik, berpikir baik dan berperilaku baik, meningkatkan bangsa yang kompetitif dalam pergaulan dunia, memperkuat dan membangun perilaku bangsa yang multikurtural (Banks, 2009).

Pendidikan karakter untuk mencapai hasil yang diharapkan dalam pengaplikasinnya, ada tiga faktor pendukung dalam mewujudkan tujuan yang dicita-citakan. Di antaranya (1) Pendidikan lingkungan keluarga, (2) Pendidikan lingkungan sekolah, (3) Pendidikan lingkungan masyarakat. Konsep yang sejalan dengan pendidikan karakter itu adalah Sekolah Alam yang menjadikan sekolah tersebut seolah-olah siswa dalam lingkungan keluarga, dalam lingkungan masyarakat dan dalam lingkungan sekolah itu sendiri

\section{Metode}

Kajian yang bertujuan untuk mengidentifikasi problem-problem kurikulum dan pembelajaran pendidikan karakter ini menggunakan metode kajian pustaka. Melalui kajian terhadap sejumlah literatur yang relevan, penelitian ini berusaha mengungkap berbagai problem yang berkenaan dengan kurikulum dan pembelajaran pendidikan karakter.

\section{Hasil dan Pembahasan}

Dalam bahasa Yunani kurikulum di ambil dari kata curere yang artinya tempat berpacu. Oxford Dictionary menyebutkan bahwa curriculum is subjects in a course of study or taught in a school, collage (Nasbi, 2017, p. 3). Menurut Zais kurikulum dapat dipahami sebagai program mata pelajaran, seperti halnya bahasa Inggris, aljabar, sejarah, ekonomi dan lainnya (Zais, 1976, p. 7). Dengan kata lain kurikulum mencakup suatu daftar atau judul mata pelajaran yang disampaikan oleh sekolah. Pandangan lain menyebutkan bahwa kurikulum ialah isi mata pelajaran tertentu dalam program atau data dan informasi yang terekam dalam membimbing pelajar melalui buku catatan yang diperlukan dan disediakan dalam rencana pembelajaran.

Adapun komponen kurikulum seperti dalam konteks KTSP yang dikemukakan oleh Tita Lestari tahun 2006 yang terdiri atas empat komponen di antaranya komponen tujuan, komponen isi (bahan pengajaran), konponen strategi dan komponen evaluasi. Penjelasan dari empat komponen tersebut yaitu: (1) Komponen tujuan yang meliputi langkah-langkah sebagai: (a) analisis kebutuhan; (b) merumuskan dan menjawab pertanyaan filosofi; (c) 
menentukan desain kurikulum; (d) membuat rencana induk: pengembangan, pelaksanaan dan penilaian. (2) Komponen isi yang meliputi langkah-langkah: (a) perumusan dasar pemikiran; (b) perumusan visi, misi dan tujuan; (c) penentuan struktur dan isi program; (d) pemilihan dan pengorganisasian materi; (e) pengorganisasian kegiatan pembelajaran; (f) pemilihan sumber, alat dan sarana belajar; (g) penentuan cara mengukur hasil belajar. (3) Komponen strategi yang meliputi langkah: (a) penyusunan rencana pembelajaran; (b) penjabaran materi; (c) penentuan strategi dan metode pembelajaran; (d) penyediaan sumber, alat, dan sarana pembelajaran; (e) penentuan cara penilaian proses dan hasil belajar; dan (f) setting lingkungan pembelajaran. (4) Komponen evaluasi, yakni untuk bisa melihat sejauh mana kekuatan dan kelemahan dari kurikulum yang dikembangkan, baik bentuk penilaian formatif atau sumatif. Penilaian kurikulum dapat mencakup context, input, proses, produk (CIPP). Penilaian produk berfokus pada mengukur pencapaian proses pada akhir program (identik dengan evaluasi sumatif). Empat komponen tersebut bertujuan untuk memastikan bahwa tujuan dari kurikulum benarbenar tercapai. Sehingga kurikulum menjadi tanggung jawab para perencana, pelaksana dan pengawas pendidikan untuk menjamin bahwa pembelajaran berlangsung dengan baik.

Ruang lingkup manajemen kurikulum meliputi perencanaan, pengorganisasian, pelaksanaan, dan evaluasi kurikulum (Wahyudin, 2014). Pada satuan tingkat pendidikan manajemen kurikulum lebih mengutamakan dalam merealisasikan dan merelevansikan antara kurikulum nasional dalam bentuk standar kompetensi atau kompetensi dasar dengan kebutuhan daerah dan kondisi sekolah yang bersangkutan sehingga kurikulum tersebut merupakan kurikulum yang integritas dengan siswa maupun dengan lingkungan dimana sekolah itu berada. Studi manajemen kurikulum merupakan studi internal dari mempelajari kurikulum (Zais, 1976). Studi ini berkaitan dengan administrasi Pendidikan dimana fungsi supervisi telah mencakup di dalamnya. Jika dilihat dari pengertian kurikulum maka yang mencakup ruang lingkup manajemen kurikulum hanya mencakup usaha dalam rangka melancarkan jadwal pelajaran. Tetapi jika yang diambil pengertian kurikulum dalam arti luas, maka ruang lingkup manajemen bukan hanya dibatasi dalam ruang kelas, tetapi menyangkut pula kegiatan pengelolaan di luar kelas.

Jika dilihat dari kegiatan atau siklus kurikulum sebagaimana dimaksudkan mencakup pekerjaan yang sangat luas terutama proses menyiapkan naskah konseptual kurikulum. Adapun karakteristik perencanaan kurikulum di antaranya meliputi karakteristik perencanaan kurikulum dan pengorganisasian kurikulum (Ho, 2018). Karakteristik dalam hal perencanaan 
kurikulum terdiri dari pengertian, fungsi, model dan desain kurikulum (Milner, 2010). Di antara karakteristik perencanaan kurikulum di antaranya yaitu program sekolah harus dirancang untuk mengkoordinasikan semua unsur dalam kurikulum kerangka kerja pendidikan, perencanaan kurikulum harus berdasarkan konsep yang jelas, perencanaan kurikulum harus dibuat dalam kerangka kerja yang komprehensif, perencanaan kurikulum harus bersifat reaktif dan antisipasi, rumusan berbagai tujuan pendekatan harus diperjelas dengan ilustrasi konkret dan lain-lain (Amiruddin, 2017).

Berdasarkan pendapat tersebut dapat disimpulkan bahwa karakteristik perencanaan kurikulum perlu diperhatikan perencana kurikulum, baik dalam kerangka penyusunan kurikulum yang benar-benar baru (perumusan awal), maupun dalam rangka pengembangan kurikulum agar sasaran perencanaan kurikulum memenuhi harapan stakeholders pendidikan dan perkembangan anak didik.

Karakteristik pengorganisasian kurikulum meliputi beberapa bidang yaitu kurikulum mata pelajaran, kurikulum dengan mata pelajaran berkorelasi, kurikulum bidang studi, kurikulum integrasi dan kurikulum inti. Sebagai contoh ciri karakteristik dari bidang kurikulum mata pelajaran yang terdiri atas sejumlah mata pelajaran yang terpisah, tidak berdasarkan kebutuhan, minat, dan masalah yang dihadapi siswa, bentuk kurikulum yang tidak dipertimbangkan kebutuhan, masalah, dan tuntutan masyarakat yang senantiasa berubah dan berkembang (Amiruddin, 2017).

Manajemen kurikulum memiliki lima prinsip yang sangat penting yang harus diperhatikan di antaranya adalah: (1) Produktivitas, hasil yang akan didapat dalam sebuah kegiatan kurikulum merupakan bagian penting yang harus dipertimbangkan dengan sebaik baiknya dalam manajemen kurikulum. Pertimbangan bagaimana agar siswa dapat mencapai hasil belajar sesuai dengan tujuan kurikulum harus menjadi sasaran dalam manajemen kurikulum. (2) Demokratisasi, kegiatan manajemen kurikulum wajib berdasarkan demokrasi yang meletakkan pengelola, pelaksana serta subjek didik pada kedudukan yang seharusnya dalam melaksanakan kewajiban dengan penuh rasa tanggung jawab dalam pencapaian tujuan kurikulum. (3) Kooperatif, untuk mendapatkan hasil yang diharapkan pada kegiatan manajemen kurikulum diharapkan adanya kerja sama yang baik dari berbagai pihak yang terlibat. (4) Efektivitas dan efisiensi, urutan kegiatan manajemen kurikulum wajib mempertimbangkan efektivitas dan efisiensi guna tercapainya tujuan kurikulum sehingga kegiatan manajemen kurikulum tersebut menghasilkan yang maksimal dengan biaya, tenaga, dan waktu yang relatif singkat. (5) Mengarahkan visi, misi dan tujuan yang sudah tertuang dalam kurikulum, proses manajemen kurikulum harus dapat 
memperkuat dan mengarahkan visi, misi, dan tujuan kurikulum. (Barrett $\&$ Rata, 2014)

Kurikulum memiliki enam fungsi yang harus diperhatikan di antaranya sebagai berikut: (1) meningkatkan efisiensi pemanfaatan sumber daya kurikulum; (2) meningkatkan keadilan (equity) dan kesempatan pada peserta didik untuk mencapai hasil yang maksimal; (3) meningkatkan relevansi dan efektivitas pembelajaran sesuai dengan kebutuhan siswa maupun lingkungan sekitar; (4) meningkatkan efektivitas kinerja guru maupun aktivitas peserta didik dalam mencapai tujuan pembelajaran; (5) meningkatkan eflsiensi dan efektivitas proses belajar mengajar; dan (6) meningkatkan partisipasi masyarakat untuk membantu mengembangkan kurikulum (Lebeaume, 2011).

Perkembangan masyarakat modern tidak bisa dipisahkan dengan perkembangan studi manajemen tidak semata mata terkait dengan tujuan organisasi saja, melainkan telah berkembang pada bidang yang lain meliputi mental, moral, etika, pendidikan atau bahkan yang lebih kecil skopnya yakni kurikulum yang kesemuanya itu berkaitan dengan pencapaian tujuan. Konsep manajemen kurikulum terdiri dari empat poin penting, yaitu (1) Standar nasional pendidikan adalah pernyataan mengenai kualitas hasil dan komponen sistem yang berkenaan dengan penyelenggaraan pendidikan di seluruh wilayah hukum RI pada jenjang, jenis atau jalur pendidikan tertentu. Mencakup standar isi, pembelajaran, pengembangan tendik, sarana dan prasarana, dan evaluasi pendidikan. (2) Pengajaran ialah proses interaksi para siswa dan sumber belajar disuatu lingkungan belajar tertentu dalam upaya pendidikan tertentu. (3) Peserta didik ialah anggota masyarakat yang berusaha mengembangkan potensi dirinya melalui pengalaman belajar yang tersedia pada jalur, jenis dan jenjang pendidikan. (4) Satuan pendidikan adalah lembaga penyelenggaraan pendidikan, seperti kelompok bermain, tempat penitipan anak, taman kanak-kanak, sekolah, perguruan tinggi, kursus dan kelompok belajar (Amiruddin, 2017).

Kurikulum dalam pengembangannya terbagi menjadi dua macam yaitu manajemen pengembangan kurikulum sentralistik dan manajemen pengembangan kurikulum desentralistik. Kedua macam pengembangan ini memiliki ruang lingkup yang berbeda. Manajemen pengembangan kurikulum sentralistik merupakan pengembangan kurikulum yang bersumber dari pusat (pemerintah) dan menghasilkan kurikulum nasional. Manajemen kurikulum ini dipegang oleh pejabat pusat mulai dari wewenang, tanggung jawab, inisiatif, gagasan dan model kurikulum. Pada tabel 1 berikut diberikan ciri sentralistik kurikulum yang berlaku di Indonesia dari tahun ke tahunnya. 
Tabel 1. Ciri sentralistik pada kurikulum yang berlaku di Indonesia

\begin{tabular}{llll}
\hline No & Nama Kurikulum & Ciri Sentralistik & \\
\hline 1 & Rencana Pelajaran & Rumusan Keputusan MPRS Nomor II/MPRS/1960 \\
& 1960 & mengenai manusia sosialis Indonesia sebagai suatu bagian \\
& dari sosialisme Indonesia yang menjadi tujuan \\
& pembangunan nasional semesta berencana, yaitu tata \\
& masyarakat adil dan makmur berdasarkan pancasila. \\
& Dalam pelaksanaannya di berbagai sekolah sesuai dengan \\
& jiwa dari keputusan MPRS tersebut. Kurikulum yang \\
& berlaku tunggal dari pusat sampai daerah.
\end{tabular}

2 Kurikulum 1968 Awal masa Orde baru terdapat TAP MPRS Nomor XXVII/ MPRS/1966 tentang Agama, Pendidikan, dan kebudayaan, dirumuskan mengenai tujuan pendidikan sebagai pembentuk manusia pancasilais sejati berdasarkan ketentuan-ketentuan seperti yang dikehendaki oleh pembukaan dan isi UUD 1945. Lembaga pendidikan dan strukturnya disederhanakan, perkembangan pramuka sangat diperhatikan pemerintah. Kurikulum yang berlaku tunggal dari pusat sampai daerah.

3 Kurikulum 1975 Tujuan-tujuan pendidikan dijabarkan secara sentralistik yang dijabarkan melalui tujuan instruksional umum, tujuan instruksional umum, tujuan instruksional khusus dan berbagai dan berbagai rincian lainnya sehinga jelas apa yang akan dicapai melalui kurikulum tersebut. Kurikulum yang berlaku tunggal dan seragam dari pusat sampai daerah.

4 Kurikulum 1984 Masa ini ditandai dengan tiga ciri kebijakannya, yaitu semesta, menyeluruh dan terpadu. Kebijakan ini menghendaki satu sistem dan pengelola tunggal terhadap sistem tersebut. Kurikulum seragam pada setiap jenjang dan jenis pendidikan.

5 Kurikulum 1994 Kurikulum 1994 merupakan respons terhadap UU Nomor 2 tahun 1989 tentang sistem pendidikan nasional. UU ini memiliki semangat sentralistik yang kuat, kurikulum di atur secara nasional. Tujuan, isi, metode dan evaluasi kurikulum, serta pembelajaran masih ditentukan oleh pemerintah pusat.

6 Kurikulum 2013 Pemerintah bertanggung jawab dalam mempersiapkan guru dan kepala sekolah untuk melaksanakan kurikulum. Pemerintah bertanggung jawab dalam melakukan evaluasi pelaksanaan kurikulum secara nasional. Kurikulum seragam pada setiap jenjang dan jenis pendidikan. Perencanaan, Pelaksanaan dan evaluasi masih diatur oleh 
Tabel di atas memperlihatkan bahwa hampir semua kurikulum yang ada di Indonesia merupakan kurikulum sentralistik (kecuali kurikulum 2006). Bahkan kurikulum 2013 masih mempertahankan ciri sentralistiknya. Selain memiliki kelebihan, kurikulum sentralistik memiliki kekurangan seperti contoh wilayah yang cukup luas memiliki keragaman dalam kondisi, kebutuhan dan tingkat kemajuannya, kurikulum yang bersifat nasional tidak dapat mengakomodasi keragaman kondisi tersebut.

Kelebihan dan kekurangan jenis manajemen pengembangan kurikulum sentralistik memang sangat tergantung pada keragaman kondisi sosial, politik, budaya dan ekonomi suatu negara atau daerah. Keragaman tersebut dapat juga menjadi kekuatan dan sekaligus kelemahan yang seharusnya dapat dikelola demi terlaksananya kurikulum untuk mencapai tujuan pendidikan (Nasbi, 2017). Manajemen kurikulum desentralistik untuk penyusunan, pelaksanaan, pengelolaan dan pengendalian dilakukan secara lokal oleh satuan pendidikan. Melibatkan guru-guru, ahli, komite sekolah, dan pihak lainnya dari masyarakat yang memiliki perhatian terhadap kurikulum sekolah. Kurikulum ini biasa disebut dengan School Based Curriculum Development (SBCD) atau Kurikulum Tingkat Satuan Pendidikan (KTSP). Pengembangan kurikulum oleh satuan pendidikan akan menghasilkan desain kurikulum yang berbeda-beda, akan tetapi lebih mudah dipahami, dikuasai, dan dilaksanakan oleh guru karena mereka ikut serta dalam pengembangannya (Amiruddin, 2017, p. 51).

Tabel 2. Ciri Desentralistik Kurikulum 2006 (KTSP)

\begin{tabular}{lll}
\hline No & $\begin{array}{l}\text { Komponen } \\
\text { Kurikulum }\end{array}$ & Ciri Desentralistik \\
\hline 1 & Tujuan & Kurikulum satuan pendidikan (KTSP) adalah kurikulum \\
& & operasional yang disusun dan dilaksanakan oleh masing- \\
& & masing satuan pendidikan. Peraturan pemerintah Nomor \\
& & 19 Tahun 2005 Pasal 17 ayat (2) menyatakan bahwa \\
& sekolah dan komite sekolah,atau madrasah mengembangkan \\
& kurikulum tingkat satuan pendidikan dan silabusnya \\
& berdasarkan kerangka dasar kurikulum dan standar \\
& kompetensi lulusan, dibawah supervisi dinas kabupaten/ \\
& kota yang bertanggung jawab dibidang pendidikan SD, \\
& SMP, SMA, dan SMK serta departemen yang menangani \\
& urusan pemerintahan dibidang agama untuk MI, MTs, MA, \\
& dan MAK. Penyusunan kurikulum pada tingkat satuan \\
& pendidikan jenjang pendidikan dasar dan menengah
\end{tabular}




\begin{tabular}{lll}
\hline \multirow{3}{*}{2 Isi } & berpedoman pada paduan yang disusun oleh badan standar \\
& Nasional Pendidikan (BSNP). \\
& Latar belakang (dasar pemikiran penyusunan KTSP), tujuan \\
& pengembangan KTSP, prinsip pengembangan KTSP sesuai \\
& dengan karakteristik sekolah. \\
& Ketode $\quad \begin{array}{l}\text { Kurikulum operasional yang disusun dan dilaksanakan oleh } \\
\text { tiap-tiap satuan pendidikan. Sekolah dan kepala sekolah }\end{array}$ \\
& mengembangkan KTSP dan silabus berdasarkan kerangka \\
& dasar kurikulum, dan standar kompetensi di bawah \\
& koordinasi dan supervisi dinas pendidikan kabupaten/kota \\
& dan/atau provinsi. \\
& Evaluasi pembelajaran berbasis kelas, proses pengumpulan \\
& dan penggunan informasi oleh guru melalui sejumlah bukti \\
& untuk membuat keputusan tentang pencapaian hasil \\
& belajar/kompetensi siswa. Penilaian hasil belajar oleh satuan \\
& pendidikan bertujuan menilai pencapaian standar \\
& kompetensi lulusan untuk semua mata pelajaran. \\
\hline
\end{tabular}

Jenis kurikulum ini memiliki beberapa kelebihan dan kelemahan. Diantara kelebihannya yaitu kurikulum ini sesuai dengan kebutuhan, kondisi, karakteristik, dan perkembangan satuan pendidikan dan masyarakat setempat sehingga satuan pendidikan secara langsung atau tidak langsung dapat membantu perkembangan masyarakat. Sedangkan kelemahan yang dimiliki oleh jenis manajemen kurikulum ini di antaranya desain kurikulum sangat beragam, dapat menimbulkan kesulitan dalam pengawasan dan evaluasi kurikulum dan evaluasi hasil belajar secara nasional, tidak semua guru memiliki keahlian atau kecakapan dalam pengembangan kurikulum, atau tidak semua satuan pendidikan/daerah memiliki guru atau orang yang ahli atau cakap dalam pengembangan kurikulum.

Istilah pembelajaran dapat diartikan sebagai "seperangkat acara peristiwa eksternal yang buat untuk mendukung terjadinya proses belajar yang sifatnya internal" (Ozar, 2018). Dari pengertian ini mengisyaratkan bahwa pembelajaran merupakan proses yang sengaja direncanakan dan dirancang sedemikian rupa dalam rangka memberikan bantuan bagi terjadinya proses belajar. Pembelajaran merupakan usaha yang dilakukan untuk menjadikan orang lain belajar dan beraktivitas untuk menciptakan kreativitas peserta didik (Nazarudin, 2007, p. 162).

Dari berbagai pengertian tersebut maka dapat kita ketahui bahwa manajemen pembelajaran merupakan suatu usaha dan kegiatan yang meliputi pengaturan seperangkat program pengalaman belajar yang rancang untuk 
mengembangkan kemampuan peserta didik sesuai dengan tujuan organisasi atau sekolah. Manajemen pembelajaran meliputi proses pengelolaan dalam kegiatan belajar mengajar, yang dimulai dari proses perencanaan, pengorganisasian, pelaksanaan, pengendalian dan penilaian dalam rangka tujuan pendidikan (Suwardi, 2007, p. 1). Di dalam dunia pendidikan, manajemen pembelajaran memiliki peranan yang sangat penting. Karena manajemen pembelajaran ialah pengaturan semua kegiatan pembelajaran yang dikategorikan dalam kurikulum inti maupun penunjang. Dengan adanya manajemen pembelajaran diharapkan tujuan pembelajaran akan terpenuhi karena dengan manajemen yang baik akan berdampak pada kegiatan pembelajaran yang terarah dan mampu menciptakan kondisi pembelajaran yang optimal.

Tujuan dari pembelajaran erat kaitannya dengan tujuan pendidikan secara umum, karena pembelajaran merupakan alat untuk mencapai tujuan pendidikan secara optimal (Kusrini, 2005, p. 128). Selain itu tujuan pokok dari pembelajaran adalah untuk memperoleh cara, teknik dan metode yang sebaik-baiknya dilakukan, sehingga sumber-sumber yang sangat terbatas seperti tenaga, dana, fasilitas, material maupun spiritual guna mencapai tujuan pembelajaran secara efektif dan efisien. Di antara fungsi dari pembelajaran yaitu mempersiapkan dan mengkomunikasikan rencana-rencana dan keputusan-keputusan. Misalnya perencanaan adalah penentuan serangkaian tindakan untuk mencapai sesuatu hasil yang diinginkan. Fungsi lain dari pembelajaran sesuai dengan fungsi yang terdiri dari perencanaan pembelajaran, pelaksanaan pembelajaran dan evaluasi pembelajaran.

Pembelajaran mencakup sejumlah eleman, yaitu (1) Perencanaan pembelajaran. Perencanaan ialah menyusun langkah-langkah yang akan dilaksanakan untuk mencapai tujuan yang telah ditentukan, kegiatan pembelajaran di indikasikan dengan aplikasi prinsip-prinsip perencanaan pembelajaran di antaranya yaitu mengembangkan alternatif-alternatif yang sesuai dengan strategi pembelajaran dan mempersiapkan dan mengkomunikasikan rencana-rencana dan keputusan-keputusan yang berkaitan dengan pembelajaran kepada pihak-pihak yang berkepentingan. (2) Pelaksanaan pembelajaran. Pelaksanaan proses pembelajaran ini merupakan pelaksanaan strategi yang telah dirancang untuk mencapai tujuan pembelajaran. Pelaksanaan pembelajaran merupakan interaksi antara guru dan peserta didik dalam rangka pentransferan materi pelajaran kepada peserta didik untuk mencapai tujuan (Muchit, 2008, p. 110). Pelaksanaan pembelajaran ialah melaksanakan yang telah siapkan seperti tujuan yang telah ditentukan materi, metode serta strategi yang relevan. pelaksanaan strategi-strategi yang telah dibuat untuk mencapai tujuan pembelajaran (Syaifurrahman \& Yati, 
2013, p. 66). Fungsi pengorganisasian dalam kegiatan pembelajaran, ditunjukkan dengan beberapa indikator di antaranya yaitu menyediakan fasilitas, perlengkapan, dan personil yang diperlukan untuk menyusun kerangka yang efisien dalam melaksanakan rencana-rencana melalui suatu proses penetapan pelaksanaan pembelajaran yang diperlukan untuk menyelesaikannya. (3) Evaluasi pembelajaran. Evaluasi merupakan alat penilai hasil pencapaian tujuan dalam pengajaran yang harus dilakukan secara kontinyu. Evaluasi bukan hanya sebagai penentu angka keberhasilan belajar namun juga sebagai feedback dari pembelajaran (Ali, 2010, p. 113). Fungsi pengawasan dalam kegiatan pembelajaran, diimplikasikan dengan sejumlah indikator. Sebagian dari fungsi pengawasan tersebut yaitu menilai pekerjaan dan melakukan tindakan koreksi terhadap penyimpangan-penyimpangan, baik institusional satuan pendidikan maupun proses pembelajaran.

Kata karakter berasal dari akar kata Latin kharakter, kharassein dan kharax, yang bermakna tools for marking (membuat tanda), to engrave (mengukir), dan pointed stake (membuat tonggak) (Baehr, 2017). Awal mulanya kata ini banyak digunakan dalam bahasa Prancis caractere di abad ke 14. Namun mulai masuk ke dalam bahasa Inggris menjadi character. Sebelum akhirnya menjadi bahasa Indonesia karakter.

Karakter merupakan panduan dari segala tabiat manusia yang bersifat tetap, sehingga menjadi tanda yang khusus untuk membedakan orang yang satu dengan yang lainnya (Zubaedi, 2012, p. 9). Karakter sebagai campuran kompatibel dari seluruh kebaikan yang diidentifikasikan oleh tradisi religius, cerita sastra, kaum bijaksana, dan kumpulan orang berakal sehat yang ada dalam sejarah (Lickona, 2012, p. 18). Muchlas Samani berkata bahwa karakter merupakan nilai dasar yang membangun pribadi seseorang yang terbentuk karena pengaruh hereditas maupun pengaruh lingkungan, yang membedakannya dengan manusia lainnya dan diwujudkan dalam sikap dan perilaku kehidupannya sehari-hari ( et al. Samani, 2017, p. 43). Karakter adalah ciri khas yang dimiliki oleh suatu benda atau individu. Ciri khas tersebut merupakan ciri asli dan mengakar pada kepribadian benda atau individu tersebut, yang dapat mendorong untuk bertindak, bersikap, berujar, dan merespon sesuatu. Karakter juga ciri khas setiap individu berkenaan dengan jati dirinya yang merupakan saripati kualitas batiniah atau rohaniah, cara berfikir, cara berperilaku hidup seseorang dan bekerja sama baik dalam keluarga, masyarakat bangsa maupun negara (Harman, 2000). Dari beberapa pengertian di atas maka dapat kita ambil kesimpulan bahwa karakter merupakan ciri khas seseorang dalam berperilaku yang membedakan dirinya dengan orang lain. 
Terdapat tiga komponen karakter yang baik (components of good character) di antaranya adalah: (1) Pengetahuan moral. Merupakan bagian penting dari aspek yang harus diajarkan. Bagian ini memiliki enam aspek yang menonjol di antaranya kesadaran moral, pengetahuan nilai moral, penentuan perspektif, pemikiran moral, pengambilan keputusan dan pengetahuan pribadi. Dalam pengambilan keputusan individu mampu memikirkan cara bertindak melalui permasalahan moral dengan cara ini merupakan keahlian pengambilan keputusan reflektif. Apakah konsekuensi yang ada terhadap pengambilan keputusan moral telah diajarkan bahkan kepada anak-anak pra usia sekolah. Sedangkan dengan aspek pengetahuan pribadi merupakan jenis pengetahuan moral yang sangat sulit untuk diperoleh, namun hal tersebut perlu bagi pengembangan karakter. (2) Perasaan moral. Komponen ini merupakan pembahasan aspek sifat emosional seseorang, dimana sering diabaikan pembahasannya dalam pendidikan moral, namun di sisi ini sangatlah penting. Terdapat enam aspek yang merupakan aspek emosi yang harus mampu dirasakan oleh seseorang untuk menjadi manusia berkarakter. Enam aspek emosi tersebut di antaranya hati nurani, harga diri, empati, mencintai sesuatu yang baik, kendali diri dan kerendahan hati. (3) Tindakan moral. Merupakan hasil dari dua bagian karakter lainnya. Jika seseorang memiliki kualitas moral kecerdasan serta emosi maka mereka mungkin melakukan apa yang mereka ketahui dan mereka anggap benar. Tindakan moral terdapat pada beberapa aspek, seperti kompetensi, keinginan dan kebiasaan (Wueste, 2018).

Dalam situasi yang besar, pelaksanaan tindakan moral memperoleh manfaat dari kebiasaan. Seseorang sering melakukan suatu hal yang baik karena dorongan kebiasaan. Sebagai bagian dari pendidikan moral, setiap anak memerlukan banyak kesempatan untuk mengembangkan kebiasaan yang baik, banyak praktik dalam hal menjadi orang yang baik.

Karakter terdiri dari delapan elemen, yaitu dorongan-dorongan, insting, refleks-refleks, sifat-sifat karakter, sentimen, minat, kebajikan dan kemauan. Dorongan-dorongan merupakan elemen karakter yang sudah ada sejak lahir dalam rangka untuk memenuhi kebutuhan-kebutuhan hidup tertentu. Seperti dorongan makan, dorongan aktif dan dorongan bermain. Insting merupakan kemampuan untuk melakukan hal-hal kompleks yang dilakukan tanpa latihan sebelumnya pada tujuan yang berarti. Biasanya insting dibawa sejak lahir, sehingga tidak disadari dan berlangsung secara mekanistis (Burroughs, 2018).

Refleks-refleks merupakan reaksi yang dilakukan tanpa disadari yang berlaku diluar kesadaran. Sifat-sifat karakter di antaranya kebiasaan dan kecenderungan-kecenderungan atau hasrat yang tertuju pada satu tujuan tertentu. Sentimen adalah semacam perasaan atau kesadaran yang mempunyai kedudukan sentral, dan menjadi sifat karakter yang utama. Kemauan adalah 
dorongan kehendak yang terarah kepada tujuan tertentu dan dikendalikan oleh pertimbangan akal pikiran.

Pendidikan karakter yang berasal dari dua kata yaitu pendidikan dan karakter. Beberapa ahli menuturkan bahwa kata pendidikan mempunyai definisi yang berbeda-beda tergantung pada sudut pandang, paradigma, metodologi dan disiplin keilmuan yang digunakan.

Pendidikan karakter, dengan demikian, adalah sistem penanaman nilainilai karakter kepada warga sekolah yang meliputi komponen pengetahuan, kesadaran, kemauan, dan tindakan yang meliputi komponen pengetahuan, sikap, dan keterampilan (Jerome et al., 2019a). Pendidikan karakter adalah diberikannya tempat bagi kebebasan individu dalam menghayati nilai-nilai yang dianggap sebagai baik, luhur, dan layak diperjuangkan sebagai pedoman bertingkah laku bagi kehidupan pribadi berhadapan dengan dirinya dan Tuhan (Arthur, 2003). Pendidikan karakter merupakan pendidikan budi pekerti plus yang melibatkan aspek pengetahuan, perasaan dan tindakan.

Secara umum pendidikan karakter bertujuan untuk membentuk manusia secara utuh yang berkarakter, yaitu dengan mengembangkan aspek fisik, emosi, sosial, kreativitas, spiritual, dan intelektual siswa secara optimal (Jerome, Kisby, Jerome, \& Kisby, 2019b). Sedangkan secara spesifik tujuan dari pendidikan karakter dimaksudkan untuk memfasilitasi peserta didik mengembangkan karakter terutama tercakup dalam butir-butir standar kompetensi lulusan. Tujuan dari pendidikan karakter khususnya dalam setting sekolah di antaranya adalah untuk menguatkan dan mengembangkan nilai-nilai kehidupan yang dianggap penting dan perlu sehingga menjadi kepribadian atau kepemilikan peserta didik yang khas sebagaimana nilai-nilai yang dikembangkan (Koesoema, 2010). Pendidikan karakter juga bertujuan untuk meningkatkan mutu penyelenggaraan dan hasil pendidikan yang mengarah pada pencapaian pembentukan karakter dan akhlak mulia peserta didik secara utuh, terpadu dan seimbang. Dengan demikian, menurut penulis tujuan pendidikan karakter memiliki fokus pada pengembangan potensi peserta didik secara keseluruhan, agar dapat menjadi individu yang siap menghadapi masa depan dan mampu survive mengatasi tantangan zaman yang dinamis dengan perilaku-perilaku yang terpuji (Park, 2004).

Pendidikan karakter perlu didasarkan pada prinsip-prinsip mempromosikan nilai-nilai dasar etika sebagai basis karakter; mengidentifikasi karakter secara komprehensif supaya mencakup pemikiran, perasaan, dan perilaku; (3) menggunakan pendekatan yang tajam, proaktif dan efektif untuk membangun karakter; (4) menciptakan komunitas sekolah yang memiliki kepedulian; (5) memberi kesempatan kepada peserta didik untuk menunjukkan perilaku yang baik; (6) memiliki cakupan terhadap kurikulum 
yang bermakna dan menantang yang menghargai semua peserta didik, membangun karakter mereka, dan membantu mereka untuk sukses; (7) mengusahakan lahirnya motivasi diri pada para peserta didik; (8) memfungsikan seluruh staf sekolah sebagai komunitas moral yang berbagi tanggung jawab untuk pendidikan karakter dan setia pada nilai dasar yang sama; (9) adanya pembagian kepemimpinan moral dan dukungan luas dalam membangun inisiatif pendidikan karakter; (10) memfungsikan keluarga dan anggota masyarakat sebagai mitra dalam usaha membangun karakter; dan (11) mengevaluasi karakter sekolah, fungsi staf sekolah sebagai guru-guru karakter, dan manifestasi karakter positif dalam kehidupan peserta didik (Walker, Roberts, \& Kristjánsson, 2015).

Dalam rangka memfasilitasi pengembangan diri anak peserta didik, diperlukan berbagai nilai karakter. Pendidikan karakter dianggap sebagai pendidikan nilai moralitas manusia yang disadari dan dilakukan dalam tindakan nyata. Nilai tersebut dapat membantu dalam berinteraksi bersama orang lain secara lebih baik. Nilai tersebut mencakup dari berbagai bidang di dalam kehidupan seperti hubungan dengan sesama, diri sendiri, hidup bernegara maupun dengan lingkungan (Curren, 2018).

Terdapat 25 nilai karakter yang menjadi prioritas di antaranya kereligiusan, kejujuran, kecerdasan, tanggung jawab, kebersihan dan kesehatan, kedisiplinan, tolong menolong, berfikir logis, kesantunan, ketangguhan, kedemokratisan, kemandirian, keberanian mengambil resiko, berorientasi pada tindakan, berjiwa kepemimpinan, kerja keras, percaya diri, keingintahuan, cinta ilmu, kesadaran, kepatuhan terdapat aturan-aturan sosial, menghargai karya, kepedulian terhadap lingkungan, nasionalisme dan menghargai keberagaman. Di antara dari poin nilai karakter tersebut yaitu kedisiplinan, yaitu tindakan yang menunjukan perilaku tertib dan patuh pada berbagai ketentuan dan peraturan. Seperti contoh dari nilai kedisiplinan yaitu datang dan pulang sekolah tepat waktu, memakai seragam sesuai ketentuan sekolah dan mengatur waktu untuk belajar dan untuk yang lainnya. Contoh lain dari nilai karakter yaitu kemandirian yang merupakan sikap dan perilaku yang tidak mudah tergantung pada orang lain dalam menyelesaikan tugas-tugas.

Selain itu Kementrian Pendidikan Nasional melansir bahwa dari kajian nilai-nilai agama, norma-norma sosial, hukum, etika akademik dan prinsip HAM terdapat 80 nilai karakter yang dikelompokkan menjadi 5 bagian penting (Gunawan, 2012, p. 32). Di antara kelima nilai tersebut yaitu: (1) nilai-nilai perilaku manusia yang berhubungan dengan tuhan yang maha esa, (2) nilai-nilai perilaku manusia yang berhubungan dengan diri sendiri, (3) nilai-nilai perilaku manusia yang berhubungan dengan sesama manusia, (4) 
nilai-nilai perilaku manusia yang berhubungan dengan lingkungan, (5) nilainilai perilaku manusia yang berhubungan dengan kebangsaan.

Di dalam proses pendidikan karakter akan menghadirkan nilai-nilai dari berbagai dunia seperti pada aspek simbolik, empirik, etik, estetik, etik, sinnoetik dan sinoptik. Dalam prosesnya, pendidikan karakter seharusnya mampu mengembangkan unsur-unsur karakter dengan praktik pendidikan yang mementingkan bisa bertumbuhnya kesadaran diri. Dalam penerapan pendidikan karakter di sekolah lebih banyak berurusan dengan penanaman nilai, pendidikan karakter agar dapat di sebut integral dan utuh mesti perlu juga mempertimbangkan berbagai macam metode yang bisa membantu mencapai idealisme dan tujuan pendidikan karakter. Doni A Koesoema mengemukakan lima metode dalam pendidikan karakter dalam penerapan di lembaga sekolah, di antaranya mengejarkan, keteladanan, menentukan prioritas, praksis prioritas dan refleksi (Baehr, 2017).

Pendidikan karakter tentu saja memiliki sejumlah metode. Metodemetode itu antara lain (1) Mengajarkan. Dalam metode ini adalah memberikan pemahaman kepada peserta didik tentang struktur nilai tertentu, seperti kebaikan, keadilan dan nilai sehingga peserta didik memahami apa itu yang dimaksud dengan kebaikan, keadilan dan nilai. Mengajarkan memiliki dua faedah yaitu memberikan pengetahuan konseptual baru dan menjadi pembanding atas pengetahuan yang dimiliki peserta didik. Basis pelaksanaannya berupa dialog adalah memberikan kesempatan peserta didik untuk mengajukan apa yang dipahaminya, apa yang dialaminya, apa yang pernah dialaminya dan bagaimana perasaannya berkenan dengan konsep yang diajarkan. (2) Keteladanan. Peserta didik akan banyak mempelajari dari apa yang dia lihat. Metode ini merupakan metode yang menjadi bagian dari hal klasik berhasilnya sebuah tujuan Pendidikan karakter. Guru adalah jiwa bagi Pendidikan karakter karena guru dapat menentukan warna kepribadian anak didik. Meskipun keteladanan tidak hanya bersumber dari guru saja, tetapi juga bersumber dari orang tua, kerabat dan siapapun yang sering berhubungan dengan peserta didik. (3) Menentukan prioritas. Umumnya lembaga sekolah memiliki prioritas atas karakter yang ingin diterapkan di lingkungan mereka. Penentuan prioritas yang jelas harus ditentukan agar proses evaluasi atas berhasil tidaknya pendidikan karakter sehingga dapat menjadi jelas. Ketidakjelasan tujuan dan tata cara evaluasi pada gilirannya akan memundurkan keberhasilan program pendidikan karakter. Untuk itu prioritas akan nilai pendidikan karakter ini harus dirumuskan dengan jelas dan tegas, diketahui oleh setiap pihak yang terlibat di dalam proses pendidikan tersebut. Sekolah sebagai lembaga publik, memiliki tanggung jawab untuk memberikan laporan pertanggungjawaban kinerja pendidikan mereka secara transparan 
kepada pemangku kepentingan yaitu masyarakat luas (Davis, 2018). (4) Praksis prioritas. Unsur lain yang tak kalah pentingnya bagi pendidikan karakter adalah pembuktian dilaksanakannya prioritas nilai pendidikan karakter tersebut. Ini sebagai tuntutan lembaga pendidikan atas prioritas nilai yang menjadi visi kinerja pendidikannya, sekolah sebagai lembaga pendidikan seharusnya mampu membuat verifikasi sejauh mana visi sekolah yang telah direalisasikan dalam lingkup pendidikan skolastik melalui berbagai macam unsur yang ada di dalam lembaga pendidikan itu sendiri. Verifikasi atas tuntutan di atas adalah bagaimana pihak sekolah menyikapi pelanggaran atas kebijakan sekolah, bagaimana sanksi itu diterapkan secara transparan sehingga menjadi praksis secara kelembagaan. Realisasi visi dalam kebijakan sekolah merupakan salah satu cara untuk mempertanggungjawabkan pendidikan karakter itu di hadapan publik. (5) Refleksi. Disebut juga dengan proses bercermin, mematut-matutkan diri pada peristiwa atau konsep yang telah teralami. Atau metode ini adalah kemampuan sadar khas manusiawi. Dengan kemampuan ini, manusia mampu mengatasi diri dan meningkatkan kualitas hidupnya agar menjadi lebih baik (Narvaez \& Lapsley, 2008).

Bangsa Indonesia telah bertekad dalam mencerdaskan bangsa hingga sejajar dengan bangsa lain di dunia. Gunawan dalam Permata tahun 2017 mengemukakan bahwa seperti yang terdapat dalam Undang-Undang Dasar 1945 alinea ke empat yang berbunyi: “.....mencerdaskan kehidupan bangsa...." dan selanjutnya yang terdapat dalam pasal 31 bahwa setiap warga negara berhak mendapatkan pengajaran (Gunawan, 2012, p. 1). Jika dilihat dari sejarah bangsa Indonesia, Pendidikan karakter bukan suatu hal yang baru yang ada dalam tradisi Indonesia. Pendidikan karakter sebagai bentuk kepribadian dan identitas bangsa seperti yang diterapkan oleh para pendidik terdahulu seperti Kartini, Soekarno dan Mohammad Hatta.

\section{Problematika Kurikulum Pendidikan Karakter}

Kurikulum dalam sebuah lembaga atau sebuah negara mempunyai peran sangat penting, dan kurikulum itu senantiasa terus berkembang menyesuaikan diri dari zaman ke zaman, sedangkan problematika, berasal dari akar kata bahasa inggris "problem" artinya, soal, masalah atau teka-teki. Juga berarti problematik, yaitu ketidak tentuanagar peserta output dan siswa atau peserta didik bisa dengan mudah mengikuti perkembangan yang ada. Ada empat masalah yang harus diperhatikan meliputi bidang cakupan, artikulasi relevansi dan kemampuan transfer. Para ahli pendidikan seperti Thorndike, Daniel dan L. N. Tanner serta Taba menyepakati bahwa jika guru hendak mentransfer nilai-nilai maka terlebih dahulu harus diperhatikan prinsip-prinsip umum dari proses transfer yaitu: (a) transfer merupakan hati nurani dan pendidikan; (b) 
proses transfer memungkinkan untuk dilakukan; (c) proses transfer dimulai dari situasi yang lebih dekat, ke situasi luar kelas yang lebih jauh dan luas; (d) hasil transfer akan lebih bermakna (meaningful) jika guru membantu siswa dalam menderivasi, generalisasi, serta menetapkan generalisasi tersebut; (e) secara umum, bisa dikatakan bahwa ketika siswa memperoleh pengetahuan bagi dirinya, proses transfer tersebut telah berhasil (Barrett \& Rata, 2014).

Adapun dalam pencapaian tujuan sebuah kurikulum terutama kurikulum yang ada di Indonesia masih banyak masalah. Masalah-masalah tersebut ikut andil dalam dampaknya terhadap pembelajaran dan pendidikan yang ada di Indonesia. Berikut ini adalah beberapa masalah kurikulum yang ada di Indonesia. Problem kurikulum di Indonesia adalah karena kurikulum pendidikan di Indonesia relatif kompleks. Apabila dilihat dengan kurikulum di Negara lain, kurikulum yang dipergunakan di Indonesia terlalu kompleks. Sehingga berakibat terhadap pengajar dan para peserta didik merasa terbebani dengan segudang materi yang harus dikuasainya, pengajar peserta didik harus bekerja keras untuk menguasai dan mengajar materi yang sudah ditargetkan. $\mathrm{Hal}$ ini akan membuat peserta didik tidak akan memahami keseluruhan materi yang diajarkan. Sehingga guru akan terbebani dengan pencapaian target materi yang terlalu banyak.

Selain itu, kurikulum pendidikan di Indonesia juga cenderung kerap berganti nama. Kurikulum yang ada di Indonesia selalu mengalami perubahan atau pergantian nama. Namun, perubahan itu hanyalah sebatas perubahan nama saja. Tanpa mengubah esensi kurikulum. Pada tataran praktik pendidikan, kurikulum juga kurang memiliki sumber untuk pengembangan. Pengembangan sebuah kurikulum tentu saja berdasarkan sumber prinsip, oleh karena itu untuk menunjukkan dari mana asal mula lahirnya suatu prinsip pengembangan kurikulum. Sumber prinsip pengembangan kurikulum yang dimaksud adalah data empiris (pengalaman yang terdokumentasi dan terbukti efektif), data eksperimen (temuan hasil penelitian), cerita/legenda yang hidup di masyarakat (folklore of curriculum), dan akal sehat (common sense) (Barrett \& Rata, 2014). Padahal, pendidikan adalah hasil peradaban suatu bangsa yang dikembangkan atas dasar suatu pandangan hidup bangsa itu sendiri, sebagai pengalaman yang memberikan pengertian, pandangan, dan penyesuaian bagi peserta didik yang menyebabkan mereka berkembang. Jadi yang dimaksud dengan problematika pendidikan adalah, persoalan atau permasalahan yang dihadapi oleh dunia pendidikan. Persoalan-persoalan pendidikan tersebut menurut Burlian Somad secara garis besar meliputi hal sebagai berikut: Satu adanya ketidakjelasan tujuan pendidikan, Dua ketidakserasian kurikulum, Tiga ketiadaan tenaga pendidik yang tepat dan cakap, Empat adanya pengukuran 
yang salah ukur, Lima adanya kekaburan terhadap landasan tingkat-tingkat pendidikan.

Problematika kurikulum pendidikan berasal dari sejumlah faktor, antara lain (1) Rendahnya pemetaan kesempatan belajar, adanya peserta didik yang putus sekolah yang tidak melanjutkan; (2) rendahnya mutu akademik; (3) rendahnya efisiensi internal karena lamanya masa studi melampaui batas waktu standar yang sudah ditentukan; (4) rendahnya efisiensi eksternal sistem pendidikan yang disebut dengan relevansi pendidikan; dan (5) terjadinya kecenderungan menurunnya akhlak dan moral yang menyebabkan lunturnya tanggung jawab dan kesetiakawanan sosial seperti terjadi tawuran.

Pelaksanaan pendidikan karakter di sekolah yang semakin hari semakin berhadapan dengan sejumlah permasalahan juga dipicu oleh (1) kurikulum bukan sebagai patokan yang baku dan statis, tetap dinamis dan menyesuaikan dengan situasi dan kondisi; (2) pendidikan karakter menjadi hanya slogan tanpa ada tindakan nyata di sekolah; (3) tidak adanya koordinasi/kerjasama antara pelaksanaan penguatan pendidikan karakter di sekolah dan lingkungan keluarga; (4) kurangnya peran guru dalam pelaksanaan pembelajaran karakter di sekolah (Supriati \& Umar, 2018).

Pendidikan karakter yang menjadi sorotan pemerintah dan para pendidik merupakan program baru yang diprioritaskan Kementrian Pendidikan dan Kebudayaan. Sebagai program baru masih menghadapi banyak problem dan kendala. Kendala-kendala tersebut adalah (1) Nilai-nilai karakter yang dikembangkan di sekolah belum terjabarkan dalam indikator yang representatif; (2) Sekolah belum memilih nilai-nilai karakter yang sesuai dengan visinya; (3) Pemahaman guru tentang konsep pendidikan karakter yang masih belum menyeluruh; (4) Guru belum dapat memilih nilai-nilai karakter yang sesuai dengan mata pelajaran yang diampunya; (5) Guru belum memiliki kompetensi yang memadai untuk mengintegrasikan nilai-nilai karakter pada mata pelajaran yang diampunya; dan (6) Guru belum dapat menjadi teladan atas nilai-nilai karakter yang dipilihnya (Judiani, 2010).

\section{Problematika Pembelajaran Pendidikan Karakter}

Proses pembelajaran pendidikan karakter di Indonesia dihadapkan pada sejumlah masalah yang dapat dibedakan menurut dua faktor, yaitu faktor internal dan eksternal. Faktor internal antara lain disebabkan oleh faktor guru atau pendidik. Kendala utama yang dihadapi oleh pengajar atau pendidik adalah adanya kesenjangan antara formasi yang tersedia dengan kebutuhan nyata. Upaya pendayagunaan guru melalui pembinaan pendidikan dan pelatihan hingga saat ini belum mencapai hasil yang maksimal. Permasalahan yang perlu mendapat perbaikan bahwa penataran yang dilakukan oleh berbagai 
unit masih belum dapat memberikan kesempatan yang merata kepada semua guru. Sistem rekrutmen guru yang ada selama ini masih belum menjamin terjaringnya calon guru yang berkualitas yang menguasai bidang studi dan mempunyai motivasi yang tinggi untuk menjadi guru. salah satu penyebab karena adanya ujian masuk atau seleksi hanya berupa pengetahuan umum yang sifatnya sementara. Upaya dengan seleksi ujian bidang studi dan ujian kemampuan mengajar didepan kelas diharapkan mampu dapat memperkecil dampak yang di timbulkan.

Ada tiga tugas pokok pendidik, yaitu transfer ilmu (transfer of knowledge), transfer nilai (transfer of value), dan transfer keterampilan (transfer of skill). Untuk itu sang pendidik mengisi tiga ranah kognitif, afektif dan psikomotor. Ranah pertama untuk mengsisi otak, ranah kedua untuk mengisi hati dan ketiga untuk mengisi keterampilan. Ketiga ini dapat juga di singkat dengan $\mathrm{H}$ 3, head (kepala), heart (hati), dan hand (tangan). Head (kepala) sebagai simbol dari ilmu, di sini pendidik mengisi otak peserta didik dengan berbagai pengetahuan, Heart (hati) adalah simbol dari jiwa, disini pendidik mengsisi jiwa (hati) peserta didik dengan nilai-nilai (values) kebajikan, mengisi afektif mereka. Hand (tangan) adalah simbol dari kerja, disini pendidik memberi keterampilan kepada peserta didik, mengisi psikomotor mereka, agar tercapai target maksimal dari ketiga ranah itu maka pendidik mesti melakukan berbagai tugas utama yakni mendidik, mengajar, membimbing, mengarahkan, melatih, menilai dan mengevaluasi. Suatu hal yang menjadi permasalahan pembelajaran pendidikan karakter kita saat ini adalah terlalu dominannya pendekatan kognitif dalam pembelajaran. Segala sesuatunya di ukur berdasarkan kemampuan akal pikiran atau pengethuanya saja, kurang mempertimbangkan aspek afektif dan psikomotor. Seseungguhnya sebuah pembelajaran yang berhasil adalah apabila pembelajaran itu di dekati dengan ketiga aspek tersebut. Seorang pendidik haruslah merancang pembelajaran yang mencapai ketiganya . Taksonomi Bloom telah memaparkan hal tersebut. Ketika sebuah mata pelajaran dengan pokok bahasan tertentu akan diajarkan oleh pendidik, maka dia sudah merancangkan pencapaian domain kognitif, afektif dan psikomotor yang akan di raihnya. Karena itu pendekatan pembelajaran itu tidak hanya pendekatan kognitif dan pencapaian aspek kognitif saja.

Faktor internal kedua adalah siswa atau peserta didik. Dalam masyarakat, ada beberapa istilah yang digunakan untuk menyebut peserta didik, seperti siswa, murid, santri, pelajar, mahasiswa dan sebagainya. Istilah siswa, murid, dan pelajar, umumnya digunakan untuk menyatakan peserta didik pada jenjang pendidikan dasar sampai sekolah menengah. Sementara pada peserta didik pada tingkat pendidikan tinggi atau akademi, disebut mahasiswa. Istilah santri sering digunakan untuk mengatakan peserta didik dipondok pesantren. 
Peserta didik adalah tiap orang atau sekelompok orang yang menerima pengaruh dari seseorang atau sekelompok orang yang menjalankan kegiatan pendidikan.

Dari kesimpulan diatas dapat diartikan bahwa peserta didik merupakan orang-orang yang sangat memerlukan pengetahuan, bimbingan, maupun arahan dari orang lain. Untuk menentukan jenis peserta didik maka tidak dapat terlepas dari jenis-jenis atau bentuk-bentuk pendidikan. Secara umum, bentuk pendidikan dibagi menjadi dua, yaitu pendidikan sekolah dan pendidikan luar sekolah.

Pendidikan merupakan sarana penting untuk meningkatakan sumber daya manusia (SDM) dalam menjamin kelangsungan pembangunan suatu bangsa dan agama. Pada masa akan datang peningkatan daya saing suatu bangsa perlu mendapat perhatian serius khususnya dalam memanfaatkan ilmu pengetahuan dan teknologi, guna menghasilkan anak didik yang berkualitas dan bermoral atau berkarakter. Dalam problematika pembelajaran pendidikan karakter kurangnya dukungan masyarakat terutama kelas menengah ke bawah untuk turut serta mensukseskannya. Selain itu kendala yang terjadi pada pembelajaran pendidikan karakter kurangnya kesadaran dalam memanamkan pembiasaan baik sehingga menjadi karakter pada diri siswa atau pelajar karena anak didik tidak terbiasa di perhatikan oleh orang tuanya, sehingga anak didik menganggap bahwa pendidikan tidak terlalu penting bagi siswa.

Selain faktor internal, problem pembelajaran juga berhadapan dengan masalah eksternal, khususnya lingkungan keluarga. Fungsi keluarga sangat begitu penting karena menjadi tempat pertama untuk belajar, mengasuh dan mensosialisasikan sesuatu pada anak, mengembangkan seluruh anggotanya agar dapat menjalankan fungsinya di masyarakat dengan baik serta memberikan kepuasan di lingkungannya yang sehat supaya tercapainya keluarga sejahtera. Keluarga merupakan aspek penting untuk menanamkan karakter pada anak sehingga anak mempunyai karakter yang baik.

Dalam proses pembelajaran, sebelum mengenal lingkungan masyarakat yang luas dan sebelum mendapat bimbingan dari lingkungan sekolah, seorang anak terlebih dahulu memperoleh bimbingan dari lingkungan keluarga. Dalam hal ini orang tua berperan sebagai pengajar utama dan pertama sedangkan si anak menjadi pelajar atau peserta didik. Namun banyak kendala yang di hadapi bahwa orang tua yang terlalu sibuk dengan aktifitas di luar, sehingga kurang dalam memberi pengajaran pendidikan karakter terhadap anaknya. Dan akibatnya banyaknya anak yang kurang sopan terhadap orang yang lebih tua dari dirinya.

lingkungan keluarga bagi kesuksesan pendidikan karakter cukup besar pengaruhnya.terutama Dari kedua orang tua, untuk pertama sekalinya seorang 
anak mengalami pembentukan watak (kepribadian) dan mendapatkan pengarahan moral.dan juga Lingkungan keluarga menjadi tempat berlangsungnya sosialisai yang berfungsi dalam pembentukan kepribadian sebagai makhluk individu, makhluk sosial, makhluk susila, dan makhluk religius. Pengalaman hidup bersama keluarga akan memberi andil yang besar dalam pembentukan karakter kepribadaian pada anak. Keluarga yang harmonis, rukun, dan damai akan mempengaruhi kondisi psikologis dan karakter seorang anak. Begitupun sebaliknya, anak yang kurang berbakti bahkan melakukan tindakan di luar moral kemanusiaan, dibebani oleh ketidak harmonisan dalam lingkungan keluarga.

Selain lingkungan keluarga, problem pembelajaran juga terkait dengan lingkungan sekolah. Pelajar atau peserta didik merupakan generasi yang akan menentukan nasib bangsa kita di kemudian hari. Karakter para pelajar yang terbentuk sejak sekarang akan sangat menentukan karakter bangsa ini di kemudian hari. Karakter pala pelajar akan terbentuk dengan baik manakala dalam proses tumbuh kembang mereka mendapatkan cukup ruang untuk mengekspresikan diri secara leluasa. Pelajar adalah pribadi yang mempunyai hak untuk tumbuh dan berkembang secara optimal sesuai dengan iramanya masing-masing.

Sekolah memiliki peran yang sangat penting dalam pembelajaran pendidikan karakter seorang pelajar. Terutama bagi pelajar yang tidak mendapatkan pembelajaran pendidikan karakter sama sekali dari lingkungan dan keluarga mereka. Ringkasnya, sekolah merupakan salah satu tempat efektif dalam internalisasi pembelajaran pendidikan karakter terhadap pelajar. Banyak kendala yang di hadapi pihak sekolah, seperti ada yang curang dalam mengerjakan tugas yang diberikan oleh guru, seperti menyontek dalam ulangan dan tidak jujur ,bolos, berbohong pada orang tua,malas untuk mengerjakan solat,kurang madiri dan tidak menghormati guru atau yang lebih dewasa ,berbicara tidak sopan dan lainnya.

Lingkungan berikutnya adalah lingkungan masyarakat. Lingkungan masyarakat kita akhir akhir ini menunjukkan gejala kemerosotan moral yang amat parah. Oleh karena itu, pilihan untuk menjadikan masyarakat sebagai pusat pendidikan karakter disamping keluarga dan sekolah tentulah tepat dan mendesak agar bangsa ini tidak terlalu lama menjadi bangsa yang sakit sebelum bertambah parah menjadi kronis, yang pada akhirnya membunuh harapan masa depan bangsa kita. Gejala kemerosotan moral di masyarakat terdeteksi karna adanya pergeseran ke arah ketidak jelasan jati diri dan karakter bangsa.

Banyaknya penyimpangan-penyimpangan yang dilakukan oleh para remaja, seperti kasus narkoba, kasus bullying, kasus bentrokan atau tawuran, kasus seks bebas dan lain sebagainya. Kejahatan seperti menjadi tren pada era 
sekarang. Pemicu utama pelaku kejahatan beraksi akibat tidak memiliki keimanan sehingga mudah terpengaruhi dengan lingkungan masyarakat yang tidak baik. Dari berbagai kejadian dan fenomena yang terjadi, masyarakat hendaknya juga dapat mengambil bagian penting dalam proses pendidikan karakter. Masyarakat yang terdiri dari sekelompok atau beberapa individu yang beragam akan mempengaruhi tumbuh kembang karakter-karakter individu yang ada di lingkungan masyarakat. Jadi, masyarakat juga mempunyai tanggung jawab yang sama dalam mendidik.

\section{Kesimpulan}

Salah satu yang mempengaruhi sistem pendidikan ialah kurikulum, oleh sebab itu kurikulum berperan penting sekali. Kurikulum harus bisa mengikuti alur yang ada pada masyarakat. Kurikulum harus dapat menjawab kebutuhan masyarakat luas dalam setiap persoalan yang dihadapi. Sehingga sudah selayaknya kurikulum terus dan terus diperbaharui dan dikembangkan. Sejalan dengan zaman, tantangan di dunia pendidikan dalam rangka membekali siswa siswi menjadi pribadi lurus dan siap hidup dalam keadaan apapun. Kurikulum harus responsif dan komprehensif dalam kehidupan sosial tidak overload, relevan, dan mampu menyeimbangkan keberagaman dan keperluan dalam setiap masa. Dalam menghadapi kondisi Indonesia yang mengalami krisis moral yang disebabkan merosotnya nilai-nilai karakter bangsa, dan lahirnya para generasi yang tidak sesuai dengan tujuan pendidikan nasional. Maka perlu adanya penekanan pembelajaran pendidikan karakter.

Pendidikan karakter dijadikan sebagai alat reformasi pendidikan supaya terwujudnya apa yang diharapkan dari pendidikan karakter itu perlu kerjasama yang kuat mulai dari pemerintah pusat sebagai pemegang kebijakan. Sekolah sebagai tempat dan pelaksana pendidikan di lapangan, orang tua sebagai pembentuk karakter pertama anak dan lingkungan sebagai lapangan pengaplikasian pendidikan karakter sehingga semua unsur menjalankan fungsinya masing-masing. Kesatu kurikulum bukan sebagai patokan yang baku dan statis, tetap dinamis dan menyesuaikan dengan situasi dan kondisi yang ada. Kedua pendidikan karakter menjadi hanya slogan tanpa ada tindakan nyata di sekolah. Ketiga tidak adanya koordinasi/kerjasama antara pelaksanaan penguatan pendidikan karakter di sekolah dan lingkungan keluarga. Keempat kurang adanya peran guru dalam pelaksanaan pembelajaran karakter di sekolah. Adapun problem yang lain, yaitu: nilai-nilai karakter yang dikembangkan di sekolah belum terjabarkan dalam indikator yang representatif; sekolah belum memilih nilai-nilai karakter yang sesuai dengan visinya; pemahaman guru tentang konsep pendidikan karakter yang masih 
belum menyeluruh; guru belum dapat memilih nilai-nilai karakter yang sesuai dengan mata pelajaran yang diampunya; guru belum memiliki kompetensi yang memadai untuk mengintegrasikan nilai-nilai karakter pada mata pelajaran yang diampunya; dan guru belum dapat menjadi teladan atas nilai-nilai karakter yang dipilihnya.

\section{DAFTAR PUSTAKA}

Ali, M. (2010). Guru dalam Proses Belajar Mengajar. Bandung: Sinar Baru Algensindo.

Amiruddin, et al. (2017). Manajemen Kurikulum. Medan: Perdana Publishing. Arthur, J. (2003). Education with Character. In Education with Character. https://doi.org/10.4324/9780203220139

Baehr, J. (2017). The Varieties of Character and Some Implications for Character Education. Journal of Youth and Adolescence, 46(6), 1153-1161. https://doi.org/10.1007/s10964-017-0654-z

Banks, J. A. (2009). Multicultural Education: Characteristics and Goals. In J. A. Banks \& C. A. McGee (Eds.), Multicultural Education: Issues and Perspectives. New York: John Wiley and Sons.

Barrett, B., \& Rata, E. (Eds.). (2014). Knowledge and the Future of the Curriculum. https://doi.org/10.1057/9781137429261

Burroughs, M. D. (2018). Ethics Across Early Childhood Education. In Ethics Across the Curriculum-Pedagogical Perspectives (pp. 245-260). https://doi.org/10.1007/978-3-319-78939-2_15

Curren, R. (2018). Sustainability Ethics Across the Curriculum. In Ethics Across the Curriculum-Pedagogical Perspectives (pp. 273-287). https://doi.org/10.1007/978-3-319-78939-2_17

Davis, M. (2018). Moral Theory in Ethics Across the Curriculum? In Ethics Across the Curriculum-Pedagogical Perspectives (pp. 39-54). https://doi.org/10.1007/978-3-319-78939-2_3

Gunawan, H. (2012). Pendidikan Karakter Konsep dan Implementasi. Bandung: Alfabeta.

Harman, G. (2000). The Nonexistence of Character Traits. Proceedings of the Aristotelian Society (Hardback), 100(1), 223-226. https://doi.org/10.1111/j.0066-7372.2003.00013.x

Ho, O. N. K. (2018). Rethinking the Curriculum. https://doi.org/10.1007/978981-10-8902-2

Jerome, L., Kisby, B., Jerome, L., \& Kisby, B. (2019a). Character Education in Historical Context. In The Rise of Character Education in Britain (pp. 29- 
55). https://doi.org/10.1007/978-3-030-27761-1_3

Jerome, L., Kisby, B., Jerome, L., \& Kisby, B. (2019b). Three Case Studies of Character Education in Practice. In The Rise of Character Education in Britain (pp. 83-106). https://doi.org/10.1007/978-3-030-27761-1_5

Judiani, S. (2010). Implementasi Pendidikan Karakter di Sekolah Dasar melalui Penguatan Pelaksanaan Kurikulum. Jurnal Pendidikan Dan Kebudayaan, 16(3), 280-289.

Koesoema, D. (2010). Pendidikan Karakter Strategi Mendidik Anak di Zaman Global. Jakarta: Grasindo.

Kusrini, et al. (2005). Keterampilan Dasar Mengajar (PPL 1) Berorientasi pada Kurikulum Berbasis Kompetensi. Malang: Fakultas Tarbiyah UIN Malang.

Lebeaume, J. (2011). Between Technology Education and Science Education. In Positioning Technology Education in the Curriculum (pp. 75-86). https://doi.org/10.1007/978-94-6091-675-5_7

Lickona, T. (2012). Mendidik Untuk Membentuk Karakter: Bagaimana Sekolah dapat Memberikan Pendidikan Sikap Hormat dan Bertanggung Jawab. Jakarta: Bumi Aksara.

Milner, H. R. (2010). Culture, Curriculum, and Identity in Education. In Culture, Curriculum, and Identity in Education (pp. 1-11). https://doi.org/10.1057/9780230105669_1

Muchit, S. (2008). Pembelajaran Kontekstual. Semarang: Rasail Media Grup.

Mulyasa, E. (2012). Manajemen Pendidikan Karakter. Jakarta: Bumi Aksara.

Narvaez, D., \& Lapsley, D. K. (2008). Teaching Moral Character: Two Alternatives for Teacher Education. The Teacher Educator, 43(2), 156172. https://doi.org/10.1080/08878730701838983

Nasbi, I. (2017). Manajemen Kurikulum: Sebuah Kajian Teoretis. Makasar: FTK UIN Makasar.

Nazarudin. (2007). Manajemen Pendidikan. Yogyakarta: Teras.

Ozar, D. T. (2018). Identifying Learning Objectives and Assessing Ethics Across the Curriculum Programs. In Ethics Across the CurriculumPedagogical Perspectives (pp. 55-71). https://doi.org/10.1007/978-3-31978939-2_4

Park, N. (2004, January). Character Strengths and Positive Youth Development. Annals of the American Academy of Political and Social Science, Vol. 591, pp. 40-54. https://doi.org/10.1177/0002716203260079

Samani, et al. (2017). Konsep dan Model: Pendidikan Karakter. Bandung: Remaja Rosda Karya.

Samani, M., \& Hariyanto. (2011). Konsep dan Model Pendidikan Karakter. Bandung: Remaja Rosda Karya. 
Supriati, A., \& Umar, M. (2018). Optimization of the Civic Education as the Effort to Strengthen National Character in Multicultural Community. https://doi.org/10.2991/acec-18.2018.46

Suwardi. (2007). Manajemen Pembelajaran, Mencipta Guru Kreatif dan Berkompetensi. Salatiga: STAIN Salatiga Press.

Syaifurrahman, \& Yati. (2013). Manajemen dalam Pembelajaran. Jakarta: PT Indeks.

Wahyudin, D. (2014). Manajemen Kurikulum. Bandung: Remaja Rosda Karya.

Walker, D. I., Roberts, M. P., \& Kristjánsson, K. (2015). Towards a New Era of Character Education in Theory and in Practice. Educational Review, 67(1), 79-96. https://doi.org/10.1080/00131911.2013.827631

Wueste, D. E. (2018). Linking Academic Integrity and Ethics Across the Curriculum: Groundwork for Sustainability in Practical and Professional Ethics. In Ethics Across the Curriculum-Pedagogical Perspectives (pp. 303326). https://doi.org/10.1007/978-3-319-78939-2_19

Zais, R. S. (1976). Curriculum Principles and Foundation. New York: Harper and Row Publishers.

Zubaedi. (2012). Desain Pendidikan Karakter Konsepsi dan Aplikasinya dalam Dunia Pendidikan. Jakarta: Kencana. 